\title{
Fifty years of Studies
}

\author{
E. M. Swiderski
}

Published online: 27 November 2010

(C) Springer Science+Business Media B.V. 2010

This issue marks the fiftieth anniversary of a journal with a divided identity, as indicated by two consecutive titles. Founded in 1960-1961 as "SST"-Studies in Soviet Thought the journal metamorphosed in 1993 into "SEET"-its present incarnation. As SST the journal was to reflect a clear research methodology defined by its founder, J. M. Bochenski, in his programmatic lead article to SST 1961, 1; "On Soviet Studies." The Communist world was, according to Bochenski, an exceedingly complex and dynamic reality, though often misrepresented and misunderstood as a result of the woefully inadequate preparation of many of those who undertook to comment on it. He wrote: "Sovietology [both in general and with reference to 'philosophical sovietology'] is a very difficult field of research (italics in the original). (...) it is a discipline [with] a highly questionable privilege of being loved by a large crowd of dilettantes and cranks. Who is not interested in Communism and in the Soviet Union? Hundred, if not thousands, of people who do not understand a word of Russian, who do not know even the ABCs of the subject and of its methods, [yet] are constantly writing and talking about it." So great was Bochenski's conviction with regard to the skills needed to understand the communist phenomenon that he, together with a handful of students and colleagues, established, in 1958, what was to be a unique institution ... the Institute of East European Studies attached to the chair of modern and contemporary philosophy in the University of Fribourg. The Institute became a philosophical think tank devoted to careful, systematic research into Soviet thought as well as a training ground for future students of Soviet philosophy.

The skills required included knowledge of the Russian language, Russian history, Marxism and its history, Leninism (including the Stalinist form), and the history and organization of the Soviet Communist Party (and its affiliates). In Fribourg-in the early sixties a quaint, atmospheric medieval town, cows and sheep grazing virtually

E. M. Swiderski ( $\square)$

Université de Fribourg, Portes de Fribourg, 1763 Granges-Paccot, Switzerland

e-mail: Edward.Swiderski@unifr.ch 
within a stone's throw from Miséricorde (the main building of the Catholic University) and the Albertinum (the residence of an august group of Dominicans, each of whom was an acknowledged master in his academic field) with a splendid glimpse of the préalpes beckoning to anyone with a mind to trek and climb-a full program of study was implemented to ensure this basic proficiency. It was assumed that this preparation was an accompaniment to philosophical studies at the university, the outcome of which would be, for the diligent student, a doctorate obtained for a dissertation on some theme from Soviet philosophy.

In the Preface to the same SST no. 1 Bochenski notes with evident relish that in the course of the 2 years since its founding the Institute's members and external collaborators had already produced eighteen volumes and moreover had launched what counts among the major scholarly contributions of 'Fribourg' sovietologythe systematic preparation of the bibliography of Soviet philosophy. Some of these volumes became the founding texts of Sovietica, the monograph series accompanying SST, also published by Kluwer in Dordrecht (today absorbed by Springer), which when it ceased publication following the demise of the Soviet Union numbered no less 57 volumes!

Bochenski was assisted, indeed seconded, by Thomas J. Blakeley ("Tom” for all who knew him), who edited the journal from his offices at Boston College until his untimely death in 1988. Throughout those years, the journal carried the names of three affiliated institutions on its front cover: the Institute in Fribourg, the Geschwister-Scholl Institute in the University of Munich (directed by one of Bochenski's closest collaborators, Nikolaus Lobkowicz), and Boston College, thus ensuring an international scope.

Bochenski prided himself on being an 'analytical' philosopher, one who practiced 'hard' analysis in the style and according to the canons of rigour of the Lwow-Warsaw school (founded by Kazimierz Twardowski). While he was not dogmatic in this respect, being as well an accomplished historian of philosophy (cf. the classic history of philosophical logic, the history of 'contemporary' European philosophy, a study which contained, unusually, a chapter on philosophy in the Soviet Union), his analytic bent helped to define how he and his disciples approached Soviet philosophy of the day. SST was meant to be a kind of ongoing report and analysis of Soviet philosophy as a current of thought developing within the Soviet bloc as a whole, but especially in Soviet Russia. While background (history, culture, leading political personalities) certainly had to be taken into consideration, it remains that the kind of research published in the first decade or so of SST's existence had to do above all with arguments, with concepts, large and small scale philosophical theory, ranging over the problems which at that time exercised Soviet philosophers. SST, in other words, became the counterpart to the kinds of publications by Soviet philosophers appearing in Voprosy filosofii as well as in such long-lived monograph series as 'Nad čem rabotajut, o čem sporjat filosofy', that is, the aim was 'systematic'. It was not unusual to read articles in SST pointing to interesting, innovative work by Soviet philosophers, though the terms 'interesting' and 'innovative' had a meaning which could not be dissociated from constraints arising out of the Soviet mirovozzrenie. 
This last caveat notwithstanding, the first decade of SST, more or less, was a dynamic period, given that it was a time when in the Soviet Union the so-called 'thaw' exercised a positive effect on philosophy as well (giving rise to the generation of thinkers known today as the 'shest'desjatniki'). Things took a turn for the worse in Soviet philosophy following the forceful disruption of the Prague Spring and the proclamation of the Brezhnev Doctrine. Ideologically, the seventies in the Soviet Union became the era of the 'naučno-tekhničeskaja revoljucija', on the one hand, as well as rhetoric about 'real' or 'developed' socialism and the 'socialist way of life', on the other. These were not auspicious years for the journal, in part because not a few students of Soviet philosophy lost interest in studying the now somewhat tedious, monotonous works of their Soviet counterparts that later, with the advent of the perestrojka, would come to be associated with system-wide 'stagnation' (zastoj), raising calls for 'novoe myslenie'. Throughout the seventies, a number of texts did appear in SST written by philosophers who had left the Soviet Union and were re-examining to some degree particular tenets as well as the general line of Soviet thinking. Nevertheless, skimming the pages of the journal over the course of a decade or so, into the early ' 80 s, one cannot but notice the shift away from 'living' Soviet thought to, among other things, studies on Marx and Marxism generally, the history of pre-Revolutionary Russian thought, Eurocommunism, Chinese Marxism, even analytic studies devoted to, for instance, the prospects for dialectical logic, and the like. At the time the journal benefited from the expertise of several German scholars associated with the Bundesinstitut für ostwissenchaftlichen Studien in Bonn (later Berlin), whose detailed 'reports' and discussions of developments in Soviet ideology as well as philosophy appeared in English translation thanks to Blakeley's painstaking efforts (a job which in due course the undersigned assumed). It must be admitted that SST was slow in the uptake as regards developments in Soviet thinking starting in the mid-1980s prompted by Gorbachev's call for reforms. As if to acknowledge Hegel's remark about the Owl of Minerva, examination of late Soviet philosophy did not begin to appear on the pages of the journal until after the collapse of the Soviet system.

Not without reason, it was Bochenski himself who made it plain that SST had run its course. In the November issue of 1991, his article appeared entitled "Did we not waste our time?" In it, he addressed the legacy of philosophical sovietology, so much of which owed its inspiration to him.

It is hardly necessary to insist on the fact that we are witnessing the downfall, in several countries, of Soviet Communism and together with it the disappearance of its theory, Marxism-Leninism. Moreover, the general hypothesis is quite probable that Marxism-Leninism is at an end everywhere. If this is the case, then those who dedicated themselves to Marxism-Leninism are in a tragic plight-for many their life-works seem to crumble. Less poetically expressed, they have to face difficult problems.

But in this last respect they are not alone. If Communism collapses generally, then we too, the members and co-workers of the Fribourg Institute of East European Studies, would have to confront the urgent question: did we not waste our time and energy studying a doctrine that was to disappear so soon and so completely? (295) 
Bochenski takes a double line in answering his own question. On the one hand, like so many others at the time, he too is surprised that Communism collapsed; it was an event he could not have foreseen. "Reasoning by analogy with great religions ... we assumed that Marxism-Leninism will be a durable doctrine. These religions, which acted on large masses of people, survived a 1,000 years and more. Now, as Communism was similarly a faith acting on millions, we thought that it too would exhibit the kind of persistence typical of the great religions" (296-297). But, on the other hand, notwithstanding the unexpected, Bochenski comforted himself by drawing a number of general philosophical lessons from the rise and fall of communism, in particular that there was no better example than Soviet thinking of the systematic and pernicious confusion of science and Weltanschauung (which as an extreme form of 'contextualism' is by his lights utterly alien to the scientificphilosophical-spirit).

However rueful Bochenski may have been in acquiescing to history's verdict, his 'parting words' as a philosophical sovietologist could provide little comfort to the editorial board for whom the question became - should we go on, and if so, how? The journal officially adapted its present title in 1993, following a round of internal discussions, not all of which achieved agreement and consensus. There were voices among us who, citing the example of disbanded journals' such as Problems of Communism, believed that the time had come for SST to disappear gracefully into the sunset- 'we' had done our job. Some, having come to this conclusion, stepped down from the board. However, the rising tide of the 'transition', the excitement generated across the former Communist world by the promise of revitalized and variegated thinking, freed from Marxist-Leninist dogma and tapping into resources that were at once culturally specific yet hopefully responsive to European and global concerns ... all this and more suggested to others among us that a reconstructed journal had a life to look forward to. Moreover, in a way that had not on the whole been possible for SST - the 'new' journal could pursue direct contact with 'East European' philosophers, a few of whom-initially from Russia, Czechoslovakia, Poland, Hungary-were invited to join the editorial board.

Our internal debates about the journal's identity concerned the question whether we should retain a philosophical profile sensu stricto or embrace the emerging 'cultural studies' paradigm along with 'history of ideas', perhaps even 'political theory given the central importance for post-communist societies and polities (not to mention thinking) of the rule-of-law, civil society, democratic procedures, etc. At least one thing was clear-there could no longer be one guiding idea for the journal as represented by the kind of programmatic text Bochenski had produced in 1961. The situation, for the editor at least, has been rather like that Wittgenstein fixed by the phrase 'make up the rules as you go along', evidenced by, among other things, the many and varied thematic issues prepared in collaboration with 'guest editors'. The policy of thematic issues has paid dividends of more than one kind: concentrated discussion of aspects of a single theme augments the attractiveness of the individual presentations precisely as 'contributions', at times in dialogue, sometimes explicitly, sometimes implicitly.

That said, it is noteworthy, I think, that however much the journal remains committed to 'East European thought', the preponderant emphasis nevertheless has 
fallen on Russia, as if to underline continuity with SST. Upcoming planned issues confirm this tendency, as does indeed the present anniversary issue, all the materials of which bear on aspects of thinking in Russia throughout the course of the twentieth century. I am particularly pleased to say that all of our authors in this issue are members of the editorial board and represent, in different ways, the consecutive stages of SST/SEET. Particular thanks for their collaboration go to Professors Kline (who was kind enough to comment on an initial draft of this text) and Scanlan, both of whom go back to the beginnings, but of course to the others as well who over the last several years have provided invaluable support and insight to help steer SEET. 